Article

\title{
Immunization of Rabbits with Recombinant Human Cytomegalovirus Trimeric versus Monomeric gH/gL Protein Elicits Markedly Higher Titers of Antibody and Neutralization Activity
}

\author{
Xinle Cui ${ }^{1, *}$, Zhouhong Cao ${ }^{1}$, Shuishu Wang ${ }^{2}$, Michael Flora ${ }^{3}$, Stuart P. Adler ${ }^{4}$, \\ Michael A. McVoy ${ }^{5}$ and Clifford M. Snapper ${ }^{1}$ \\ 1 Department of Pathology, Uniformed Services University of the Health Sciences, Bethesda, MD 20814, USA \\ 2 Department of Biochemistry, Uniformed Services University of the Health Sciences, Bethesda, \\ MD 20814, USA \\ 3 Department of Anatomy, Physiology and Genetics, Uniformed Services University of the Health Sciences, \\ Bethesda, MD 20814, USA \\ 4 CMV Research Foundation, Richmond, VA 23229, USA \\ 5 Department of Pediatrics, Virginia Commonwealth University, Richmond, VA 23298, USA \\ * Correspondence: xinle.cui@usuhs.edu; Tel.: +1-301-295-3498; Fax: +1-301-265-1640
}

Received: 1 June 2019; Accepted: 24 June 2019; Published: 28 June 2019

\begin{abstract}
Congenital human cytomegalovirus (HCMV) infection and HCMV infection of immunosuppressed patients cause significant morbidity and mortality, and vaccine development against HCMV is a major public health priority. HCMV envelope glycoproteins $\mathrm{gB}, \mathrm{gH}$, and $\mathrm{gL}$, which constitute the core fusion machinery, play critical roles in HCMV fusion and entry into host cells. $\mathrm{HCMV} \mathrm{gB}$ and $\mathrm{gH} / \mathrm{gL}$ have been reported to elicit potent neutralizing antibodies. Recently, the $\mathrm{gB} / \mathrm{gH} / \mathrm{gL}$ complex was identified in the envelope of HCMV virions, and $16-50 \%$ of the total $\mathrm{gH} / \mathrm{gL}$ bound to $\mathrm{gB}$, forming the $\mathrm{gB} / \mathrm{gH} / \mathrm{gL}$ complex. These findings make the $\mathrm{gB} / \mathrm{gH} / \mathrm{gL}$ a unique HCMV vaccine candidate. We previously reported the production of HCMV trimeric $\mathrm{gB}$ and $\mathrm{gH} / \mathrm{gL}$ heterodimers, and immunization with a combination of trimeric $\mathrm{gB}$ and $\mathrm{gH} / \mathrm{gL}$ heterodimers elicited strong synergistic HCMV-neutralizing activity. To further improve the immunogenicity of $\mathrm{gH} / \mathrm{gL}$, we produced trimeric $\mathrm{gH} / \mathrm{gL}$. Rabbits immunized with HCMV trimeric $\mathrm{gH} / \mathrm{gL}$ induced up to 38-fold higher serum titers of $\mathrm{gH} / \mathrm{gL}$-specific IgG relative to HCMV monomeric $\mathrm{gH} / \mathrm{gL}$, and elicited $\sim 10$-fold higher titers of complement-dependent and complement-independent HCMV-neutralizing activity for both epithelial cells and fibroblasts. HCMV trimeric $\mathrm{gH} / \mathrm{gL}$ in combination with HCMV trimeric $\mathrm{gB}$ would be a novel promising HCMV vaccine candidate that could induce highly potent neutralizing activities.
\end{abstract}

Keywords: human cytomegalovirus (HCMV); vaccine; HCMV gB; HCMV gH/gL; core fusion machinery; neutralizing antibody; congenital infection; solid organ transplantation; hematopoietic stem cell transplantation

\section{Introduction}

Human cytomegalovirus (HCMV) is an enveloped, double-stranded DNA $\beta$-herpesvirus of the Herpesviridae family. HCMV causes infection in $40 \%$ to $60 \%$ of the population in industrialized countries and $80-100 \%$ of the population in developing countries [1,2]. Congenital HCMV infection of neonates and the infection of transplant recipients and patients with HIV/AIDS cause significant morbidity and mortality, though HCMV infection in immunocompetent individuals is generally 
asymptomatic [1-5]. Congenital HCMV infection is the leading non-genetic cause of hearing loss in childhood, and it is the most common infectious cause of brain damage in developed countries [1,2,6-8]. Additional diseases caused by congenital HCMV infection include chorioretinitis resulting in vision loss, hepatitis, intracranial calcifications, seizures, cerebral palsy, microcephaly and neurodevelopmental delay $[1,2,6,7]$. HCMV infection causes end-organ diseases such as hepatitis and pneumonitis in solid organ and hematopoietic stem cell transplant patients, and HCMV viremia could significantly increase the chance of graft rejection, graft failure, and in hematopoietic stem cell transplant patients, graft-versus-host disease [9-12]. The incidence of HCMV infection remains high despite active monitoring and management with antiviral drugs, ranging from $20 \%$ to $70 \%$ in the first year post-transplantation, and in solid organ and hematopoietic stem cell transplant recipients, HCMV infection remains one of the most common complications affecting patient survival [13-17].

HCMV is spread horizontally via saliva and urine, and transplacentally to the fetus $[18,19]$. The target cells of HCMV include epithelial cells, endothelial cells, monocyte-macrophages, hepatocytes, fibroblasts, and neurons [20-22]. HCMV enters cells by fusing its envelope with either the plasma membrane or endosomal membrane, which is a mechanism that is analogous to that employed by other members of the herpesvirus family [20-23]. HCMV envelopes glycoproteins gB, gH, gL, and gO, as well as the UL128, UL130, and UL131A proteins have collectively been identified as playing critical roles in HCMV fusion and entry into host cells $[20,22]$. The gB protein is the direct mediator of HCMV fusion with all the host cell membranes, and the activation of HCMV gB requires its association with the $\mathrm{gH} / \mathrm{gL} / \mathrm{gO}$ protein complex $[24,25]$. For the HCMV infection of epithelial and endothelial cells, an alternative protein complex consisting of $\mathrm{gH} / \mathrm{gL}$ with UL128, UL130, and UL131A (the pentameric complex) is further required for efficient targeting [20,23,26,27].

There is currently no HCMV vaccine approved for clinical use, although the development of an HCMV vaccine is a public heath priority. Over the past 50 years, a variety of experimental vaccine approaches have been evaluated, and many are currently in various stages of evaluation [28-31]. An HCMV vaccine consisting of an adjuvanted recombinant monomeric gB protein has advanced the furthest in clinical trials [32,33]. Specifically, several phase I and phase II clinical trials utilizing a recombinant monomeric HCMV gB in microfluidized adjuvant 59 (MF59) have been completed and demonstrated approximately 50\% efficacy in the prevention of HCMV infection [19,34-37]. The recombinant $\mathrm{gB}$ used in these clinical trials was originally developed at Chiron Corporation (Chiron $\mathrm{gB})$, and was expressed as a truncated, secreted polypeptide [38]. The Chiron gB did not recapitulate the trimeric conformation of native $\mathrm{gB}$ expressed on the envelope of virions or on the surface of HCMV-infected cells, and therefore, recombinant gB proteins expressing conformational epitopes could potentially elicit broader and highly efficient vaccine responses [38,39].

We previously reported the production of a HCMV trimeric $\mathrm{gB}$ by the insertion of a flexible 15 amino acid $\left(\mathrm{Gly}_{4} \mathrm{Ser}\right)_{3}$ linker at the furin cleavage site that allowed for terminal protein folding and efficient expression [40]. HCMV trimeric gB induced significantly higher serum titers of gB-specific IgG relative to a HCMV monomeric $\mathrm{gB}$ similar to the Chiron $\mathrm{gB}$, and elicited markedly higher complement-dependent and complement-independent HCMV-neutralizing activities [40]. More importantly, compared to the monomeric $\mathrm{gB}$, the trimeric $\mathrm{gB}$ elicited markedly higher cross-strain neutralization activities against several clinical HCMV strains as well as a variant of strain AD169 $\left(\mathrm{AD} 169^{\mathrm{wt} 131}\right)$ that expresses a functional pentameric complex [40].

We recently reported that immunization with the combination of HCMV envelope proteins trimeric gB, gH/gL, and/or UL128/UL130/UL131A elicited strong synergistic HCMV-neutralizing activities, and predicted that the combination of trimeric $\mathrm{gB}$ with $\mathrm{gH} / \mathrm{gL}$ or the pentameric complex might be ideal HCMV vaccine candidates [41]. The discovery that in the envelope of HCMV virions, up to $50 \%$ of $\mathrm{gH} / \mathrm{gL}$ complexed with $\mathrm{gB}$ makes the concept of a vaccine comprised of trimeric $\mathrm{gB}$ with $\mathrm{gH} / \mathrm{gL}$ even more attractive [42]. However, since immunization with recombinant HCMV monomeric $\mathrm{gH} / \mathrm{gL}$ only elicited moderate neutralizing activity, the trimerization of the protein would substantially increase its overall immunogenicity, including the induction of neutralizing antibodies, as described 
generally for protein multimerization [43-47]. The use of a combination of HCMV trimeric gB with trimeric $\mathrm{gH} / \mathrm{gL}$ could significantly increase the efficacy of the HCMV vaccine candidate [41].

\section{Results}

\subsection{Production of Monomeric and Trimeric HCMV gH/gL Recombinant Proteins}

We previously designed DNA constructs to produce in Chinese hamster ovary cells $(\mathrm{CHO})$ the recombinant HCMV trimeric $\mathrm{gB}$ protein as well as the recombinant $\mathrm{gB}, \mathrm{gH} / \mathrm{gL}$, and gp350 proteins of Epstein Barr virus (EBV), which is another member of the human herpesviruses family $[40,43,47]$. In the current study, we took a similar approach to design DNA constructs that encode for either monomeric or trimeric HCMV gH/gL proteins (Figure 1). A 5' end IgG $\mathrm{k}$ leader sequence was introduced to promote protein secretion, followed by sequences encoding HCMV gL and gH with a (Gly $\left.{ }_{4} \mathrm{Ser}\right)_{3}$ linker in between to allow for the proper folding of both proteins (Figure 1A-D). HCMV gL functions as a chaperon protein for $\mathrm{gH}$, and the expression of the gL protein first, followed by $\mathrm{gH}$, would ensure the correct folding of the $\mathrm{gH}$ protein. The foldon trimerization domain coding sequence derived from $\mathrm{T} 4$ phage fibritin would promote the $\mathrm{gH} / \mathrm{gL}$ trimer folding into its terminal form (Figure 1C,D). A His 6 tag sequence was added to the $3^{\prime}$ end of the DNA constructs encoding for recombinant proteins to allow for efficient purification.

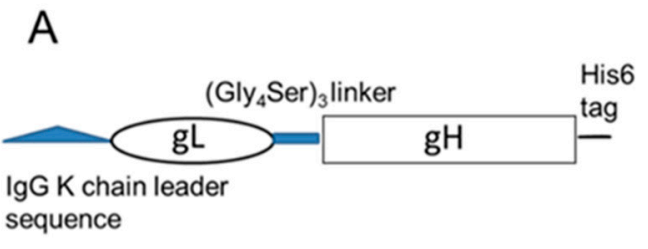

B

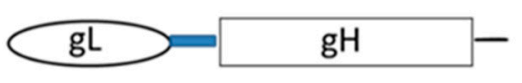

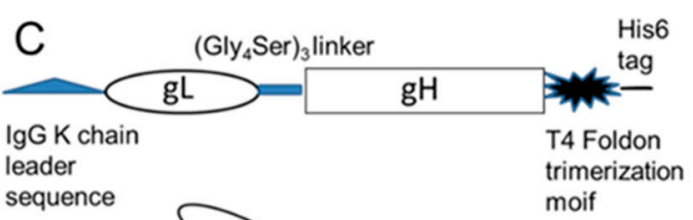

D

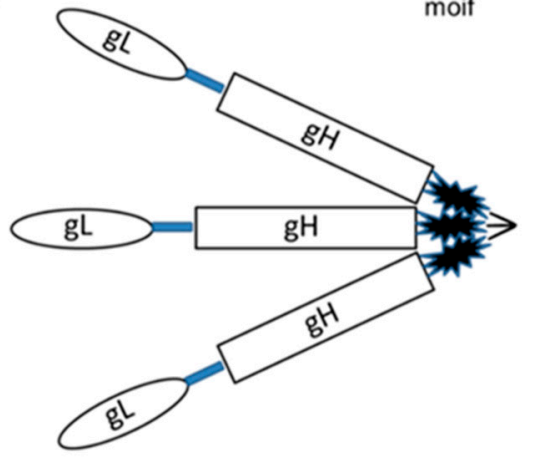

Figure 1. DNA constructs encoding human cytomegalovirus (HCMV) monomeric and trimeric gH/gL. (A) Diagram of the DNA sequences for production of monomeric HCMV gH/gL. (B) Diagram of recombinant HCMV monomeric $\mathrm{gH} / \mathrm{gL}$ protein. (C) Diagram of the DNA sequences for the production of HCMV trimeric $\mathrm{gH} / \mathrm{gL}$. (D) Diagram of recombinant HCMV trimeric $\mathrm{gH} / \mathrm{gL}$ protein.

Synthesized DNA coding for monomeric or trimeric $\mathrm{gH} / \mathrm{gL}$ was cloned into pOptiVEV (Thermo Fisher Scientific, Waltham, MA, USA) and transfected CHO cells. Following selection with increasing concentrations of methotrexate, stable $\mathrm{gH} / \mathrm{gL}$ expressing $\mathrm{CHO}$ cell lines were generated by limiting dilution cloning. Then, $\mathrm{CHO}$ cells were cultured in a FiberCell bioreactor (FiberCell Systems, Frederick, MD, USA). The supernatants were concentrated for affinity purification using a cobalt column (Thermo Fisher Scientific, Waltham, MA, USA), and further purified using size exclusion chromatography on a Superdex 200 column (GE Lifesciences, Pittsburgh, PA, USA). Western blot analysis of the monomeric $\mathrm{gH} / \mathrm{gL}$ protein using an anti-HCMV gH monoclonal antibody under either reducing conditions or modified non-reducing conditions demonstrated a single size band of $\sim 110 \mathrm{kDa}$, which is consistent with $\mathrm{gH} / \mathrm{gL}$ heterodimers (Figure 2A,C). Western blot analysis of the trimeric gH/gL protein under reducing conditions disrupted the trimeric structure, and showed a single size band of $\sim 110 \mathrm{kDa}$ (Figure 2B). Under modified non-reducing conditions, Western blot analysis of the trimeric $\mathrm{gH} / \mathrm{gL}$ 
protein demonstrated a single size band of $\sim 330 \mathrm{kDa}$, which is consistent with a trimer of the $\mathrm{gH} / \mathrm{gL}$ heterodimer (Figure 2D).
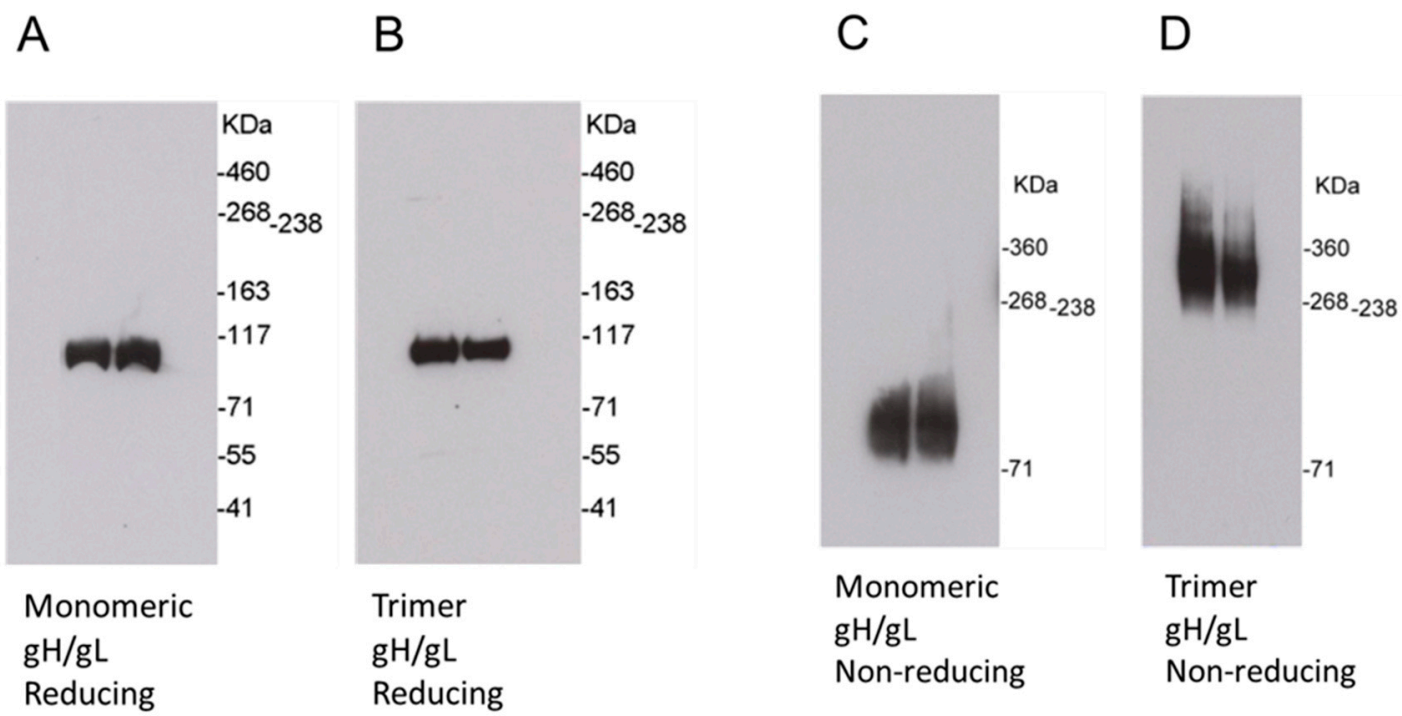

Figure 2. Western blot analysis of HCMV monomeric and trimeric $\mathrm{gH} / \mathrm{gL}$ recombinant proteins under reducing and non-reducing conditions. Secreted proteins were purified with affinity purification and size exclusion chromatography from culture supernatants of stable Chinese hamster ovary $(\mathrm{CHO})$ cell lines. (A,B) Blots of HCMV monomeric and trimeric $\mathrm{gH} / \mathrm{gL}$ recombinant proteins developed with an anti-HCMV gH monoclonal antibody under reducing conditions. (C,D) Blots of HCMV monomeric and trimeric $\mathrm{gH} / \mathrm{gL}$ recombinant proteins developed with an anti-HCMV gH monoclonal antibody under non-reducing conditions.

2.2. HCMV Trimeric $g H / g L$ Protein Induced Markedly Higher Serum Titers of $g H / g L-S p e c i f i c ~ I g G$ Relative to Monomeric $g H / g L$

We directly compared HCMV monomeric and trimeric $\mathrm{gH} / \mathrm{gL}$ for the elicitation of total serum titers of gH/gL-specific IgG. Groups of five adult rabbits each were immunized subcutaneously with $25 \mu \mathrm{g}$ of HCMV monomeric or trimeric $\mathrm{gH} / \mathrm{gL}$ recombinant protein adjuvanted with alum + CpG-ODN, and then boosted in a similar fashion on days 21 and 42 post-immunization. The CpG-ODN sequence was optimized for use in rabbits [48]. As illustrated in Figure 3, both the HCMV monomeric and trimeric $\mathrm{gH} / \mathrm{gL}$ proteins induced augmented serum IgG responses following the first booster immunization, and further significant augmentation in serum IgG titers following the second booster immunization. HCMV trimeric $\mathrm{gH} / \mathrm{gL}$ induced 29-fold and 38-fold higher serum $\mathrm{gH} / \mathrm{gL}$-specific IgG titers relative to monomeric $\mathrm{gH} / \mathrm{gL}$ following the primary immunization and the first booster immunization respectively, with the difference of titers decreased to threefold after the second booster immunization (Figure 3). These data are consistent with our previous study in mice and rabbits using monomeric and multimeric EBV envelope proteins gp350 and $\mathrm{gH} / \mathrm{gL}$, in which the multimerization of proteins induced a marked increase in immunogenicity [43,47]. 


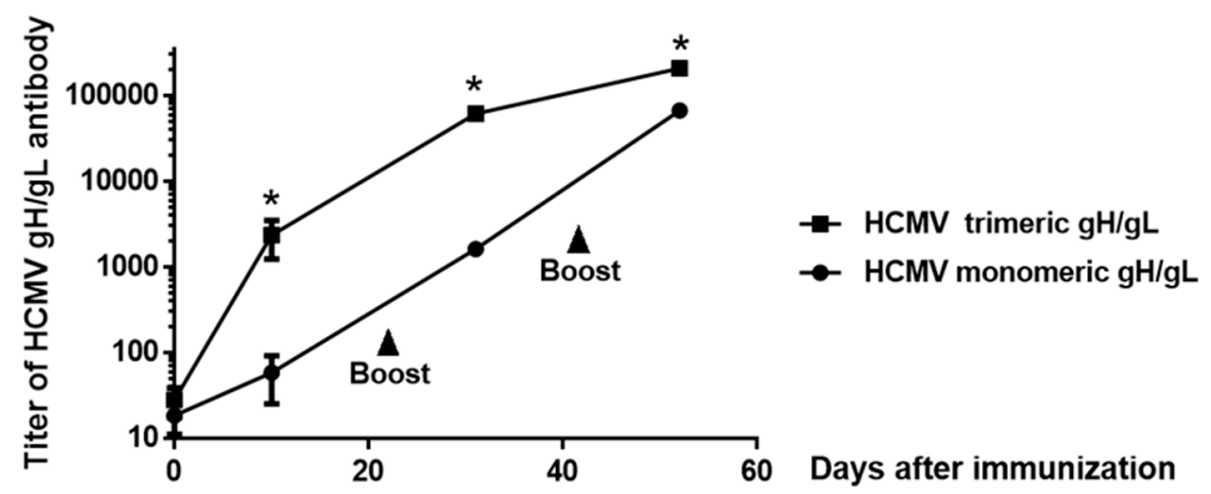

Figure 3. Serum titers of gH/gL-specific IgG following immunization with HCMV monomeric and trimeric $\mathrm{gH} / \mathrm{gL}$ recombinant proteins. Groups of rabbits, $12-15$ weeks old $(n=5)$ were immunized subcutaneously with $25 \mu \mathrm{g}$ of HCMV monomeric versus trimeric $\mathrm{gH} / \mathrm{gL}$ recombinant protein adjuvanted with alum + CpG-ODN, and boosted on days 21 and day 42 post-immunization. Sera were obtained 10 days following each immunization for the measurement of serum titers of $\mathrm{gH} / \mathrm{gL}$-specific IgG by ELISA. Significance * $p<0.05$.

2.3. Immunization of Rabbits with HCMV Trimeric $g H / g L$ Protein Elicited Significantly Higher HCMV-Neutralizing Antibodies for Epithelial Cells Relative to Monomeric $g H / g L$

Multimeric proteins are known to be significantly more potent in the elicitation of virus neutralizing antibodies, as demonstrated by an EBV tetrameric gp350 [47]. Tetrameric gp350 elicited 20-fold to 40-fold higher EBV neutralizing antibodies compared to monomeric gp350 after immunization in mice [47]. In the current study, the HCMV-neutralizing antibodies of day 52 sera from the rabbits immunized with three doses of $25 \mu \mathrm{g}$ each of HCMV trimeric versus monomeric $\mathrm{gH} / \mathrm{gL}$ were analyzed using ARPE-19 epithelial cells and HCMV strain AD169 ${ }^{\text {wt131 }}$, the HCMV strain AD169 variant expressing a functional pentameric complex. Without heat inactivation to preserve the complement activity, sera from rabbits immunized with HCMV monomeric $\mathrm{gH} / \mathrm{gL}$ showed moderate complement-dependent HCMV-neutralizing antibodies, and the sera from rabbits immunized with HCMV trimeric $\mathrm{gH} / \mathrm{gL}$ demonstrated 11-fold higher complement-dependent HCMV-neutralizing antibodies relative to HCMV monomeric $\mathrm{gH} / \mathrm{gL}$ (Figure 4). After heat inactivation at $56^{\circ} \mathrm{C}$ for $30 \mathrm{~min}$ to inactivate the complement, the HCMV-neutralizing antibodies were both slightly decreased for the sera from rabbits immunized with HCMV monomeric and trimeric gH/gL. Compared to HCMV monomeric gH/gL, HCMV trimeric $\mathrm{gH} / \mathrm{gL}$ elicited ninefold higher complement-independent HCMV-neutralizing antibodies for epithelial cells (Figure 4).

\subsection{HCMV Trimeric gH/gL Elicited Significantly Higher Serum Titers of HCMV-Neutralizing Activity for Fibroblasts Compared to Monomeric $g H / g L$}

The HCMV-neutralizing antibodies of day 52 sera from the rabbits immunized with three doses of $25 \mu \mathrm{g}$ each of HCMV trimeric versus monomeric $\mathrm{gH} / \mathrm{gL}$ were also analyzed using MRC- 5 fibroblasts and HCMV strain AD169wt131. Sera from trimeric gH/gL-immunized rabbits, in the absence of heat inactivation to preserve complement activity, demonstrated 10.5-fold higher serum titers of HCMV-neutralizing activity relative to sera from monomeric gH/gL-immunized rabbits (Figure 5). After heat inactivation at $56^{\circ} \mathrm{C}$ for $30 \mathrm{~min}$ to inactivate the complement, the titers of HCMV-neutralizing activity slightly decreased for both groups, where the trimeric relative to the monomeric $\mathrm{gH} / \mathrm{gL}$ group still demonstrated eightfold higher serum titers of HCMV-neutralizing activity (Figure 5). 


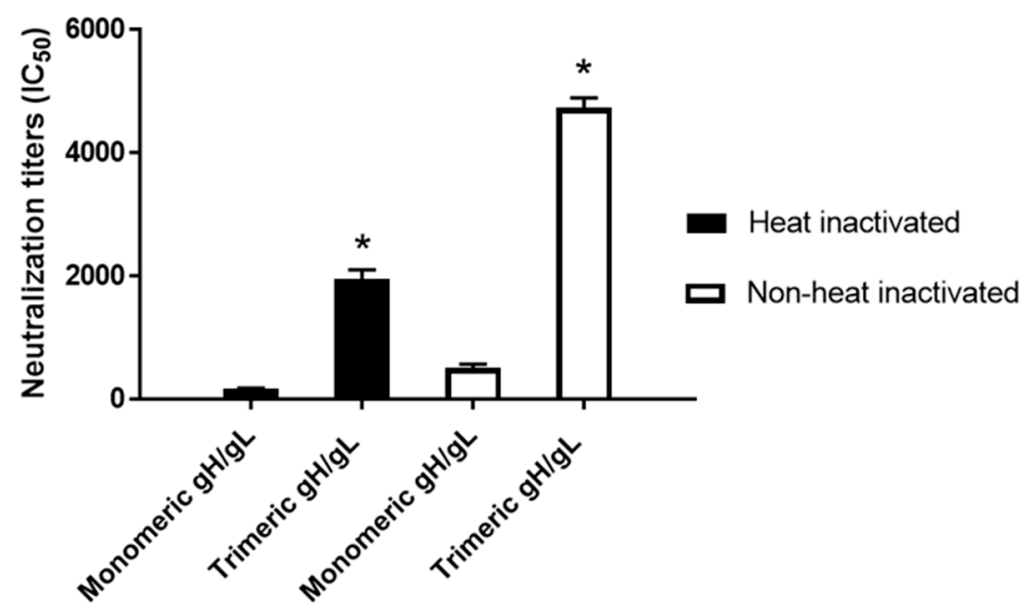

Figure 4. Immunization with HCMV trimeric gH/gL elicited significantly higher serum titers of complement-dependent and complement-independent HCMV-neutralizing activity for epithelial cells compared to monomeric gH/gL. Day 52 pooled sera from five rabbits immunized with $25 \mu \mathrm{g}$ of HCMV trimeric versus monomeric $\mathrm{gH} / \mathrm{gL}$ recombinant protein were heat-inactivated (closed bar) or non-heated (open bar), and IC50 neutralizing activity was determined of each pooled sample in quadruplicate using the ARPE-19 epithelial cell line and HCMV strain AD169 ${ }^{\text {wt131 }}$. Significance $*<0.05$ compared to the sera from rabbits immunized with HCMV monomeric $\mathrm{gH} / \mathrm{gL}$.

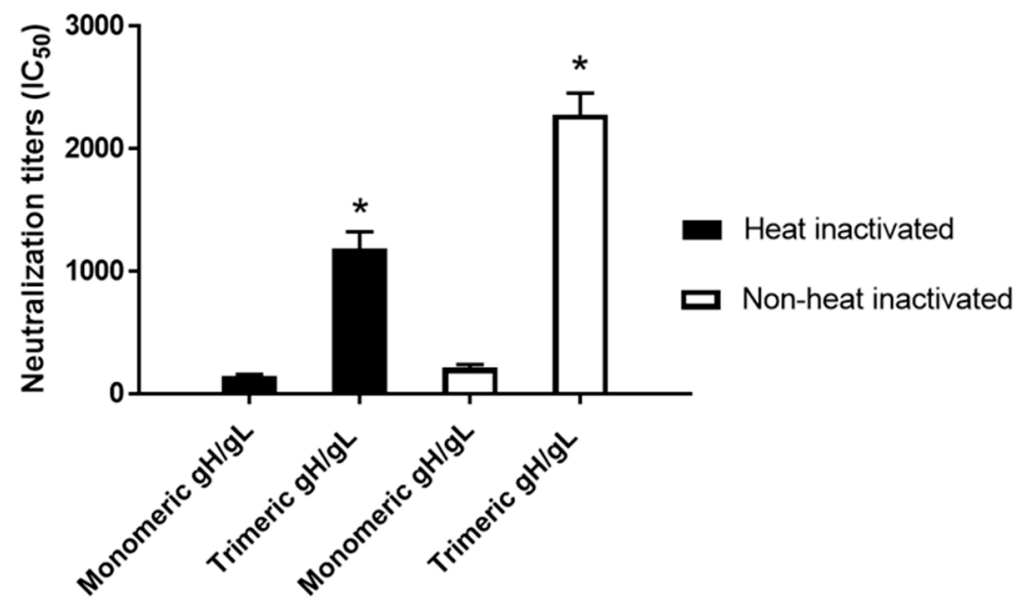

Figure 5. Immunization with $\mathrm{HCMV}$ trimeric $\mathrm{gH} / \mathrm{gL}$ elicited significantly higher complement-dependent and complement-independent serum titers of HCMV-neutralizing activity for fibroblasts compared to monomeric $\mathrm{gH} / \mathrm{gL}$ immunization. Day 52 pooled sera from five rabbits immunized with $25 \mu \mathrm{g}$ of HCMV trimeric versus monomeric $\mathrm{gH} / \mathrm{gL}$ were heat-inactivated (closed bar) or non-heated (open bar), and the IC50 neutralizing activity was determined of each pooled sample in quadruplicate using the MRC-5 fibroblast cell line and HCMV strain AD169 ${ }^{\text {wt1 } 131}$. Significance * $p<$ 0.05 compared to the sera from mice immunized with HCMV monomeric gH/gL.

\section{Discussion}

HCMV enters and infects target cells through the fusion of its envelope with either the plasma membrane or endosomal membrane, and requires multiple viral envelope proteins. Two distinct pathways have been identified as represented by the HCMV infection of fibroblast versus epithelial cells. The infection of fibroblasts involves HCMV envelope proteins $\mathrm{gB}, \mathrm{gH}, \mathrm{gL}$, and $\mathrm{gO}$, where gH, $\mathrm{gL}$, and $\mathrm{gO}$ form a protein complex [20-23]. The $\mathrm{gH} / \mathrm{gL} / \mathrm{gO}$ protein complex interacts with the fibroblast cell membrane receptor PDGF- $\alpha$, which then activates the $\mathrm{gB}$ protein for direct triggering of the virion envelope and cell membrane fusion through macropinocytosis [49-53]. The infection of epithelial cells 
with HCMV requires HCMV envelope proteins gB, gH, gL, and UL128/UL130/UL131A, where gH, gL, UL128/UL130/UL131A form a pentameric complex [20,23,26,27]. The pentameric complex binds to an epithelial cell receptor, neuropilin-2, which then triggers $\mathrm{gB}$ for endocytosis and fusion of the virion envelope with the endosomal membrane [53,54]. Although the $\mathrm{gH} / \mathrm{gL} / \mathrm{gO}$ complex is also implicated in HCMV infection of epithelial cells, its role is controversial, since epithelial cells express very low levels of PDGF $\alpha$ [53]. However, it is widely accepted that $\mathrm{gB}, \mathrm{gH}$, and $\mathrm{gL}-$ the components of the core fusion machinery-are required for infection of all the target cells with HCMV.

As these HCMV envelope proteins play critical roles in HCMV infection and entry into target cells, they have been thoroughly studied as vaccine candidates against HCMV, especially gB and the pentameric complex. In a phase II study in postpartum seronegative women within one year of giving birth, the gB/MF59 vaccine demonstrated 50\% efficacy against primary HCMV infection compared to women in the same cohort who received the placebo [19]. Another multi-center study in healthy HCMV-seronegative adolescent girls demonstrated $43 \%$ efficacy for the gB/MF59 vaccine in preventing primary HCMV infection, although the difference was not statistically significant [36]. The third phase II study of the gB/MF59 vaccine conducted in solid-organ transplant recipients demonstrated both a reduction in viremia and the total number of days requiring antiviral treatment compared to those who received placebo [37]. Further, the benefit of vaccination was most striking in HCMV-seronegative recipients of transplants from HCMV-seropositive donors, and the duration of viremia post-transplantation was inversely correlated with the magnitude of the $\mathrm{gB}$ antibody response [37]. The HCMV gB used in these clinical trials was Chiron gB, although this Chiron gB did not recapitulate the trimeric conformation of $\mathrm{gB}$ antigen expressed on HCMV virions or the surface of HCMV-infected cells, these Phase II clinical trials demonstrated 50\% efficacy in the prevention of HCMV infection, which is truly a milestone in HCMV vaccine development [28-30].

The immunogenicity of recombinant $\mathrm{HCMV} \mathrm{gB}$ can be improved by the generation of a trimeric gB expressing native conformational epitopes. We have produced a HCMV trimeric gB by insertion of a flexible 15 amino acid $\left(\mathrm{Gly}_{4} \mathrm{Ser}\right)_{3}$ linker at the furin cleavage site that allowed for terminal protein folding and efficient expression [40]. Compared to a HCMV monomeric $\mathrm{gB}$ similar to the Chiron $\mathrm{gB}$, trimeric gB induced up to 11-fold higher serum titers of gB-specific IgG, and elicited up to 50-fold higher complement-dependent and complement-independent serum HCMV neutralizing activities [40]. Importantly, compared to the monomeric $\mathrm{gB}$, the trimeric $\mathrm{gB}$ elicited markedly higher cross-strain neutralizing activity against several clinical HCMV strains and AD169 ${ }^{\text {wt131 }}$ [40].

Many preclinical studies and clinical trials have also evaluated candidate vaccines incorporating the pentameric complex. A modified vaccinia virus Ankara (MVA) vectored vaccine expressing the pentameric complex elicited potent complement-independent and complement-dependent HCMV-neutralizing antibodies after the immunization of mice [55]. Mice as well as nonhuman primates immunized with lipid nanoparticles encapsulating modified mRNA encoding the HCMV pentameric complex elicited potent and durable neutralizing antibody titers [56]. A Phase I clinical trial of a replication defective (transgenic disabled infectious singlecycle, DISC) HCMV live attenuated vaccine expressing the pentameric complex demonstrated the induction of neutralizing antibody titers that were equal to or higher than HCMV seropositive subjects analyzed with epithelial cells [28,57].

Antibodies elicited by the pentameric complex are likely to prevent HCMV infecting epithelial cells, endothelial cells, and monocytes, but not fibroblasts or primary trophoblast progenitor cells [58-65]. Since HCMV gB elicits higher HCMV neutralization activity for fibroblasts than epithelial cells, whereas the pentameric complex mainly elicits high HCMV neutralization activity for epithelial cells, endothelial cells, and monocytes, it has been suggested that an optimal prophylactic HCMV vaccine will consist of both trimeric $\mathrm{gB}$ and pentameric complex proteins [31,66]. Immunization with the combination of $\mathrm{gB}$ and the pentameric complex has been tried using RNA vaccine or the MVA vectored vaccine expressing simultaneously $\mathrm{gB}$ and the five subunits of the pentameric complex, although enhanced HCMV-neutralizing activity was induced, no synergistic or additive effects in the elicitation of HCMV-neutralizing activity was reported $[55,56]$. We recently reported 
that immunization with the combination of recombinant HCMV trimeric $\mathrm{gB}$, monomeric $\mathrm{gH} / \mathrm{gL}$, and UL128/UL130/UL131A induced strong synergistic HCMV-neutralizing activity for epithelial cells, and combined immunization with recombinant HCMV trimeric $\mathrm{gB}$ and monomeric $\mathrm{gH} / \mathrm{gL}$ elicited strong synergistic HCMV-neutralizing activity for fibroblasts [41]. As expected, the addition of UL128/UL130/UL131A to gB and gH/gL did not further increase the serum HCMV-neutralizing activity elicited for fibroblasts, since UL128/UL130/UL131A is not required for the infection of these cells with HCMV [41].

In addition to the $\mathrm{gH} / \mathrm{gL} / \mathrm{gO}$ and pentameric complexes, another $\mathrm{gH} / \mathrm{gL}$ protein complex was recently reported: the $\mathrm{gH} / \mathrm{gL} / \mathrm{gB}$ complex, or more appropriately the $\mathrm{gB} / \mathrm{gH} / \mathrm{gL}$ complex [42]. Since the core fusion machinery of HCMV consists of $\mathrm{gB}, \mathrm{gH}$, and $\mathrm{gL}$, the identification of a preformed $\mathrm{gB} / \mathrm{gH} / \mathrm{gL}$ complex in HCMV virions is striking. The $\mathrm{gB} / \mathrm{gH} / \mathrm{gL}$ complex was previously thought only to exist transiently during membrane fusion after the $\mathrm{gH} / \mathrm{gL} / \mathrm{gO}$ complex or the pentameric complex binding to cell receptors and activating $\mathrm{gB}$. More importantly, this study also showed that $\mathrm{gB}$ bound to $\mathrm{gH} / \mathrm{gL}$ early after glycoprotein synthesis in the endoplasmic reticulum, and $16-50 \%$ of the total $\mathrm{gH} / \mathrm{gL}$ bound to $\mathrm{gB}$ in the envelope of HCMV virions [42]. In contrast, the $\mathrm{gH} / \mathrm{gL} / \mathrm{gO}$ complex or the pentameric complex bound poorly to $\mathrm{gB}$ in the envelope of HCMV virions, with only $0-2 \%$ of the $\mathrm{gH} / \mathrm{gL} / \mathrm{gO}$ complex or the pentameric complex found to bind to $\mathrm{gB}$ [42]. The function of the $\mathrm{gB} / \mathrm{gH} / \mathrm{gL}$ complex is currently unknown, although it is suggested that the $\mathrm{gB} / \mathrm{gH} / \mathrm{gL}$ complex stabilizes $\mathrm{gB}$ and keeps the $\mathrm{gB}$ in pre-fusion confirmation $[42,53]$. The identification of the $\mathrm{gB} / \mathrm{gH} / \mathrm{gL}$ complex makes it a unique vaccine candidate for $\mathrm{HCMV}$, as the components of $\mathrm{HCMV}$ core fusion machinery- $\mathrm{gB}, \mathrm{gH}$, and gL-are required for HCMV fusion and enter into all the target cells. It also makes the combination of $\mathrm{gB}, \mathrm{gH}$, and $\mathrm{gL}$ a more attractive $\mathrm{HCMV}$ vaccine candidate.

$\mathrm{HCMV} \mathrm{gH} / \mathrm{gL}$ are essential components of the $\mathrm{gH} / \mathrm{gL} / \mathrm{gO}$ complex, the pentameric complex, and the $\mathrm{gB} / \mathrm{gH} / \mathrm{gL}$ complex. An anti-gH/gL human monoclonal antibody MSL-109 recognizes HCMV protein complexes containing $\mathrm{gH}$ and blocks the infection of fibroblasts by laboratory and clinical HCMV strains [67]. More importantly, an alphavirus replicon particles (VRPs) vaccine platform expressing HCMV gH/gL elicited potent, broadly cross-reactive complement-independent neutralizing antibodies against HCMV [68]. Further, the neutralizing antibodies induced by $\mathrm{gH} / \mathrm{gL}$ were significantly stronger and qualitatively different from those elicited by VRPs expressing HCMV gB (68). Although HCMV monomeric $\mathrm{gH} / \mathrm{gL}$ could elicit a potent immune response, its immunogenicity could be significantly enhanced by a multimeric form [44-46]. We have previously produced EBV tetrameric gp350 and trimeric $\mathrm{gH} / \mathrm{gL}$, which induced up to 25 -fold and 90 -fold higher antigen-specific antibody responses respectively relative to their monomeric counterparts [43,47]. EBV tetrameric gp350 elicited 20-fold to 40-fold higher neutralizing antibodies compared to monomeric gp350 analyzed with a competitive neutralizing assay, and EBV trimeric $\mathrm{gH} / \mathrm{gL}$ elicited fivefold higher neutralizing antibodies compared to EBV monomeric $\mathrm{gH} / \mathrm{gL}$ analyzed with neutralizing assay for the prevention of EBV infection of a B lymphoma cell line [43,47]. In the current study, HCMV trimeric gH/gL induced up to 38-fold higher serum titers of $\mathrm{gH} / \mathrm{gL}$-specific IgG relative to monomeric $\mathrm{gH} / \mathrm{gL}$, and elicited approximately 10-fold higher complement-dependent and complement-independent HCMV-neutralizing antibodies measured using either epithelial cells or fibroblasts. As the combination of HCMV trimeric $\mathrm{gB}$ and monomeric $\mathrm{gH} / \mathrm{gL}$ could elicit strong synergistic HCMV-neutralizing activity [41], whereas trimeric $\mathrm{gH} / \mathrm{gL}$ could induce markedly higher gH/gL-specific IgG and HCMV-neutralizing antibodies compared to monomeric $\mathrm{gH} / \mathrm{gL}$, trimeric $\mathrm{gH} / \mathrm{gL}$ can be used to replace monomeric $\mathrm{gH} / \mathrm{gL}$ in $\mathrm{HCMV}$ vaccine studies. Trimeric HCMV $\mathrm{gB}$ in combination with trimeric $\mathrm{gH} / \mathrm{gL}$ would be a novel promising HCMV vaccine candidate that could induce highly potent neutralizing activities for both fibroblast and epithelial cells. Non-neutralizing antibody functions such as antibody-dependent cell-mediated phagocytosis (ADCP) and antibody-dependent cellular cytotoxicity (ADCC) may play an important role in the prevention of HCMV infections [55,69,70]. The non-neutralizing antibody functions of the markedly higher anti-gH/gL antibodies induced by HCMV trimeric $\mathrm{gH} / \mathrm{gL}$ should be determined, in addition to their potent neutralizing activity in future studies $[55,69,70]$. 


\section{Materials and Methods}

\subsection{Cell Lines, HCMV Strains, and Reagents}

The Chinese hamster ovary (CHO) cell line DG44 was purchased from Thermo Fisher Scientific (Waltham, MA), and maintained in CD DG44 medium. MRC-5 and ARPE-19 cell lines were purchased from ATCC, and cultured using EMEM or DMEM/F-12K medium respectively, both supplemented with $10 \%$ fetal bovine serum. HCMV strain AD169 ${ }^{\text {wt131 }}$ was provided by Xiao Wang and Haruhiko Murata (Food and Drug Administration) and strain AD169 was purchased from ATCC. HCMV strain AD16 $9^{\text {wt131 }}$ was propagated in ARPE-19 cells, and HCMV strain AD169 was propagated in MRC-5 cells. Monoclonal mouse IgG1 anti-gH antibody (0861) was purchased from Santa Cruz Biotechnology (Dallas, TX, USA). Horseradish peroxidase labeled anti-mouse antibody and goat anti-rabbit antibody were purchased from Thermo Fisher Scientific (Waltham, MA, USA).

\subsection{Expression and Purification of HCMV Monomeric and Trimeric gH/gL Recombinant Proteins}

The coding sequences for HCMV gH and gL were downloaded from NCBI, reference sequence \# NC_006273.2, strain Merlin. For the trimeric gH/gL DNA expression construct, the signal peptide 1-30 of gL was replaced with an IgG $\mathrm{k}$ leader sequence, and the gL sequence encoding amino acids (AA) 31-278 was linked to the $\mathrm{gH}$ sequence encoding AA 24-718, which was separated by a 15 amino acid linker $\left(\mathrm{Gly}_{4} \mathrm{Ser}_{3}\right.$ sequence. The foldon trimerization domain coding sequence derived from $\mathrm{T} 4$ phage fibritin was linked to the $3^{\prime}$ end of $\mathrm{gH}$, followed by a His 6 coding sequence (Figure 1C). DNA coding for the trimeric $\mathrm{gH} / \mathrm{gL}$ was synthesized by Blue Heron Biotech (Bothell, WA, USA), cloned into pOptiVEV (Thermo Fisher Scientific, Waltham, MA, USA), and verified by sequencing. The HCMV monomeric $\mathrm{gH} / \mathrm{gL}$ construct was made by the PCR amplification of HCMV timeric $\mathrm{gH} / \mathrm{gL}$ with the foldon coding sequence deleted, cloned into pOptiVEV, and verified by sequencing. $\mathrm{CHO}$ cells were transfected with pOptiVEC-gH/gL monomeric or trimeric constructs using Free-style Max reagent (Thermo Fisher Scientific, Waltham, MA, USA), and selected with increasing concentrations of methotrexate up to 4 $\mu \mathrm{M}$ for optimal protein expression, followed by limiting dilution cloning. Stable $\mathrm{CHO}$ cell lines were cultured in a FiberCell bioreactor (FiberCell Systems, Frederick, MD, USA), and the supernatants were concentrated for affinity purification using a cobalt column (Thermo Fisher Scientific, Waltham, MA) following the manufacturer's instructions, and further purified using size exclusion chromatography on a Superdex 200 column (GE Lifesciences, Pittsburgh, PA, USA).

\subsection{Western Blot Analysis}

Purified proteins were analyzed by electrophoresis on 3-8\% NuPAGE Tris-Acetate Mini-Gels under reducing conditions or modified non-reducing conditions. Under reducing conditions, purified HCMV monomeric or trimeric gH/gL recombinant proteins were boiled for $10 \mathrm{~min}$ in lithium dodecyl sulfate (LDS) loading buffer containing $50 \mathrm{mM}$ of dithiothreitol (DTT), and resolved on 3-8\% PAGE in SDS running buffer. For modified non-reducing conditions, protein samples were mixed with LDS loading buffer without DTT, and resolved on 3-8\% PAGE in tris-glycine native running buffer (Thermo Fisher Scientific, Waltham, WA, USA). Proteins were transferred to membranes, and probed using a mouse monoclonal anti-gH antibody (0861) from Santa Cruz Biotechnology (Dallas, TX, USA), followed by horseradish peroxidase labeled anti-mouse antibody from Thermo Fisher Scientific (Waltham, MA, USA). Membranes were then incubated with SuperSignal West Pico chemiluminescent substrate with a signal captured on X-ray film.

\subsection{Rabbit Immunization}

Groups of five New Zealand white rabbits, $12-15$ weeks old, were immunized subcutaneously with $25 \mu \mathrm{g}$ of of HCMV monomeric or trimeric $\mathrm{gH} / \mathrm{gL}$ recombinant proteins adsorbed to aluminum hydroxide and mixed with $50 \mu \mathrm{g}$ of a 12-mer phosphorothioate-modified CPG-ODN (tcataacgttcc) optimized for rabbits (48). Rabbits were immunized on days 0,21 , and 42 , and serum samples 
were taken before the initial immunization and 10 days following each immunization. These studies were conducted in accordance with the Guide for Care and Use of Laboratory Animals (Institute of Laboratory Animal Resources, NRC), and were approved by the USUHS Institutional Animal Care and Use Committee (USUHS PAT 18-186, 2 January 2018).

\subsection{Measurement of Serum Titers of HCMV gH/gL-Specific IgG by ELISA}

Immulon 4 ELISA plates were coated overnight with $5 \mu \mathrm{g} / \mathrm{mL}$ of $\mathrm{HCMV}$ monomeric $\mathrm{gH} / \mathrm{gL}$ recombinant protein in PBS at $4{ }^{\circ} \mathrm{C}$, and blocked with $1 \%$ bovine serum albumin (BSA) in PBS. Threefold serial dilutions of serum samples in 1\% BSA-PBS were tadded and incubated overnight at $4{ }^{\circ} \mathrm{C}$, followed by washing with $0.1 \%$ Tween- 20 in PBS. Alkaline phosphatase-conjugated polyclonal goat anti-rabbit IgG (Southern Biotechnology, Birmingham, AL, USA) in 1\% BSA-PBS was added, and plates were incubated at $37^{\circ} \mathrm{C}$ for $1 \mathrm{~h}$. Plates were washed with $0.1 \%$ Tween-20 in PBS, and substrate (p-nitrophenyl phosphate, disodium; Sigma-Aldrich, St. Louis, MO, USA) was added at $1 \mathrm{mg} / \mathrm{mL}$ in tris- $\mathrm{HCl}$ magnesium-sulfate (TM) buffer for color development. Color was read at an absorbance of $405 \mathrm{~nm}$ on a Multiskan Ascent ELISA reader.

\subsection{Determination of Serum HCMV-Neutralizing Titers}

Day 52 sera from rabbits immunized with HCMV monomeric or trimeric gH/gL recombinant proteins were either heat inactivated at $56{ }^{\circ} \mathrm{C}$ for $30 \mathrm{~min}$ to eliminate complement activity or not heat-treated. Serum HCMV-neutralizing antibody titers were determined using an ELISpot assay as described [71]. Each serum sample was initially diluted at a ratio of 1:10 and prepared as 1:2 serial dilutions in cell culture medium in triplicates. Each dilution was mixed with an equal volume of culture medium containing $4000 \mathrm{pfu} / \mathrm{ml}$ HCMV strain AD169 ${ }^{\mathrm{wt} 131}[33,35,36]$, incubated for $4 \mathrm{~h}$ at $37^{\circ} \mathrm{C}$, and then added to the wells of 96-well plates containing MRC-5 or ARPE-19 monolayers and cultured overnight at $37^{\circ} \mathrm{C}$ in $5 \% \mathrm{CO}_{2}$. Cells were fixed with absolute ethanol, rehydrated, and blocked with $5 \%$ normal horse serum in PBS, followed by incubation with anti-IE1 monoclonal antibody MAB810 (Millipore, Burlington, MA, USA), goat anti-mouse secondary antibody (Jackson ImmunoResearch Labs, West Grove, PA, USA) each for $1 \mathrm{~h}$, and VECTASTAIN ABC reagent (Vector Labs, Burlingame, CA, USA) for 30 minutes. Plates were washed $3 x$ with $0.1 \%$ Tween 20 in PBS between each step, and TMB substrate (Mabtech, Inc., Cincinnati, OH, USA) was added for color development. The plates were scanned and analyzed using a CTL-ImmunoSpot $® S 6$ Micro Analyzer. Fifty percent inhibitory concentration (IC50) values and standard errors of the means were calculated using GraphPad Prism7 software by plotting the means of triplicate values for each serum dilution against the log serum dilution, calculating the best fit four-parameter equation for the data, and interpolating the inverse serum dilution at the mid-point of the curve as the IC50 neutralizing titer.

\subsection{Statistics}

All the studies were repeated at least once for reproducibility. Serum titers of antigen-specific antibodies and HCMV-neutralizing activities were expressed as geometric means $+/-$ the standard error of the mean, with significance determined by a two-tailed Student's $t$-test $(p<0.05$ is considered significant).

\section{Conclusions}

Vaccine development against HCMV is a major public health priority, as congenital HCMV infection and HCMV infection of the immunosuppressed patients cause significant morbidity and mortality. Natural immunity against HCMV infection is protective, but not complete. Subunit vaccine candidates such as recombinant HCMV envelope proteins have the potential to elicit immune responses that are quantitatively or qualitatively different from those induced by HCMV during natural infection. HCMV protein antigens expressing native conformational epitopes could elicit optimal immune responses, and the use of a combination of HCMV recombinant proteins such as the components of the 
core fusion machinery (trimeric $\mathrm{gB}$ and trimeric $\mathrm{gH} / \mathrm{gL}$ ) is a safe and efficient approach for HCMV vaccine development that could potentially provide superior protection over natural immunity.

Author Contributions: X.C. and C.M.S. designed the project. X.C., Z.C., S.W. and M.F. performed the experiments. X.C., Z.C. and S.W. developed methodology. X.C., C.M.S., M.A.M. and S.P.A. performed data analyses. X.C. and C.M.S. prepared the manuscript draft and all authors provided comments and revisions to the text and figures of the final manuscript.

Funding: This study was supported by the USUHS Dean's Research and Education Endowment Fund (CMS). USUHS had no involvement in study design, data collection, analysis or interpretation, nor writing report or decision for publication.

Acknowledgments: The authors thank Xiao Wang and Haruhiko Murata, Food and Drug Administration for providing HCMV strain AD169 ${ }^{\text {wt131. }}$

Footnotes, Mandatory Disclaimer: The opinions expressed herein are those of the authors and are not necessarily representative of those of the Uniformed Services University of the Health Sciences (USUHS), the Department of Defense (DOD), or the United States Army, Navy or Air Force.

Conflicts of Interest: Xinle Cui and Clifford M. Snapper are inventors of a patent for using trimeric herpesvirus $\mathrm{gB}$ proteins as vaccine candidates, and a pending patent for using combination of herpesvirus envelope proteins as vaccine candidates.

\section{References}

1. Demmler-Harrison, G.J. Congenital cytomegalovirus: Public health action towards awareness, prevention, and treatment. J. Clin. Virol. 2009, 46, S1-S5. [CrossRef] [PubMed]

2. Jeon, J.; Victor, M.; Adler, S.P.; Arwady, A.; Demmler, G.; Fowler, K.; Goldfarb, J.; Keyserling, H.; Massoudi, M.; Richards, K.; et al. Knowledge and awareness of congenital cytomegalovirus among women. Infect. Dis. Obstet. Gynecol. 2006, 2006, 80383. [CrossRef] [PubMed]

3. Kenneson, A.; Cannon, M.J. Review and meta-analysis of the epidemiology of congenital cytomegalovirus (CMV) infection. Rev. Med. Virol. 2007, 17, 253-276. [CrossRef] [PubMed]

4. Bonaros, N.; Mayer, B.; Schachner, T.; Laufer, G.; Kocher, A. CMV-hyperimmune globulin for preventing cytomegalovirus infection and disease in solid organ transplant recipients: A meta-analysis. Clin. Transplant. 2008, 22, 89-97. [CrossRef] [PubMed]

5. Steininger, C.; Puchhammer-Stockl, E.; Popow-Kraupp, T. Cytomegalovirus disease in the era of highly active antiretroviral therapy (HAART). J. Clin. Virol. 2006, 37, 1-9. [CrossRef]

6. Morton, C.C.; Nance, W.E. Newborn hearing screenin-A silent revolution. N. Engl. J. Med. 2006, 354, 2151-2164. [CrossRef]

7. Manicklal, S.; Emery, V.C.; Lazzarotto, T.; Boppana, S.B.; Gupta, R.K. The "silent" global burden of congenital cytomegalovirus. Clin. Microbiol. Rev. 2013, 26, 86-102. [CrossRef]

8. Bristow, B.N.; O'Keefe, K.A.; Shafir, S.C.; Sorvillo, F.J. Congenital cytomegalovirus mortality in the United States, 1990-2006. PLoS Negl. Trop. Dis. 2011, 5, e1140. [CrossRef]

9. Ramanan, P.; Razonable, R.R. Cytomegalovirus infections in solid organ transplantation: A review. Infect. Chemother. 2013, 45, 260-271. [CrossRef]

10. McIntosh, M.; Hauschild, B.; Miller, V. Human cytomegalovirus and transplantation: Drug development and regulatory issues. J. Virus Erad. 2016, 2, 143-148.

11. Reddehase, M.J. Mutual Interference between Cytomegalovirus and Reconstitution of Protective Immunity after Hematopoietic Cell Transplantation. Front. Immunol. 2016, 7, 294. [CrossRef] [PubMed]

12. Rubin, R.H. The indirect effects of cytomegalovirus infection on the outcome of organ transplantation. JAMA 1989, 261, 3607-3609. [CrossRef] [PubMed]

13. Kotton, C.N. Management of cytomegalovirus infection in solid organ transplantation. Nat. Rev. Nephrol. 2010, 6, 711-721. [CrossRef] [PubMed]

14. Beam, E.; Razonable, R.R. Cytomegalovirus in solid organ transplantation: Epidemiology, prevention, and treatment. Curr. Infect. Dis. Rep. 2012, 14, 633-641. [CrossRef] [PubMed] 
15. Ariza-Heredia, E.J.; Nesher, L.; Chemaly, R.F. Cytomegalovirus diseases after hematopoietic stem cell transplantation: A mini-review. Cancer Lett. 2014, 342, 1-8. [CrossRef] [PubMed]

16. Marty, F.M.; Ljungman, P.; Chemaly, R.F.; Maertens, J.; Dadwal, S.S.; Duarte, R.F.; Haider, M.D.; Ullmann, A.J.; Brown, J.M.D. Letermovir Prophylaxis for Cytomegalovirus in Hematopoietic-Cell Transplantation. N. Engl. J. Med. 2017, 377, 2433-2444. [CrossRef] [PubMed]

17. Razonable, R.R. Management strategies for cytomegalovirus infection and disease in solid organ transplant recipients. Infect. Dis. Clin. North Am. 2013, 27, 317-342. [CrossRef] [PubMed]

18. Krause, P.R.; Bialek, S.R.; Boppana, S.B.; Griffiths, P.D.; Laughlin, C.A.; Ljungman, P.; Mocarski, E.S.; Pass, R.F.; Read, J.S.; Schleiss, M.R.; et al. Priorities for CMV vaccine development. Vaccine 2013, 32, 4-10. [CrossRef] [PubMed]

19. Pass, R.F.; Zhang, C.; Evans, A.; Simpson, T.; Andrews, W.; Huang, M.L.; Corey, L.; Hill, J.; Davis, E.; Flanigan, C.; et al. Vaccine prevention of maternal cytomegalovirus infection. N. Engl. J. Med. 2009, 360, 1191-1199. [CrossRef]

20. Heldwein, E.E.; Krummenacher, C. Entry of herpesviruses into mammalian cells. Cell Mol. Life Sci. 2008, 65, 1653-1668. [CrossRef]

21. White, J.M.; Delos, S.E.; Brecher, M.; Schornberg, K. Structures and mechanisms of viral membrane fusion proteins: Multiple variations on a common theme. Crit. Rev. Biochem. Mol. Biol. 2008, 43, 189-219. [CrossRef] [PubMed]

22. Compton, T.; Nepomuceno, R.R.; Nowlin, D.M. Human cytomegalovirus penetrates host cells by $\mathrm{pH}$-independent fusion at the cell surface. Virology 1992, 191, 387-395. [CrossRef]

23. Ryckman, B.J.; Jarvis, M.A.; Drummond, D.D.; Nelson, J.A.; Johnson, D.C. Human cytomegalovirus entry into epithelial and endothelial cells depends on genes UL128 to UL150 and occurs by endocytosis and low-pH fusion. J. Virol. 2006, 80, 710-722. [CrossRef] [PubMed]

24. Backovic, M.; Longnecker, R.; Jardetzky, T.S. Structure of a trimeric variant of the Epstein-Barr virus glycoprotein B. Proc. Natl. Acad. Sci. USA 2009, 106, 2880-2885. [CrossRef] [PubMed]

25. Heldwein, E.E.; Lou, H.; Bender, F.C.; Cohen, G.H.; Eisenberg, R.J.; Harrison, S.C. Crystal structure of glycoprotein B from herpes simplex virus 1. Science 2006, 313, 217-220. [CrossRef] [PubMed]

26. Hahn, G.; Revello, M.G.; Patrone, M.; Percivalle, E.; Campanini, G.; Sarasini, A.; Wagner, M.; Gallina, A.; Milanesi, G.; Koszinowski, U.; et al. Human cytomegalovirus UL131-128 genes are indispensable for virus growth in endothelial cells and virus transfer to leukocytes. J. Virol. 2004, 78, 10023-10033. [CrossRef] [PubMed]

27. Wang, D.; Shenk, T. Human cytomegalovirus UL131 open reading frame is required for epithelial cell tropism. J. Virol. 2005, 79, 10330-10338. [CrossRef] [PubMed]

28. Schleiss, M.R.; Permar, S.R.; Plotkin, S.A. Progress toward development of a vaccine against congenital cytomegalovirus infection. Clin. Vaccine Immunol. 2017, 24. [CrossRef]

29. Diamond, D.J.; La Rosa, C.; Chiuppesi, F.; Contreras, H.; Dadwal, S.; Wussow, F.; Bautista, S.; Nakamura, R.; Zaia, J.A. A fifty-year odyssey: Prospects for a cytomegalovirus vaccine in transplant and congenital infection. Expert Rev. Vaccines 2018, 17, 889-911. [CrossRef]

30. Nelson, C.S.; Herold, B.C.; Permar, S.R. A new era in cytomegalovirus vaccinology: Considerations for rational design of next-generation vaccines to prevent congenital cytomegalovirus infection. NPJ Vaccines 2018, 3, 38. [CrossRef]

31. Cui, X.; Snapper, C.M. Development of novel vaccines against human cytomegalovirus. Hum. Vaccin. Immunother. 2019, 1-11. [CrossRef]

32. Fu, T.M.; An, Z.; Wang, D. Progress on pursuit of human cytomegalovirus vaccines for prevention of congenital infection and disease. Vaccine 2014, 32, 2525-2533. [CrossRef]

33. Rieder, F.; Steininger, C. Cytomegalovirus vaccine: Phase II clinical trial results. Clin. Microbiol. Infect. 2014, 20, 95-102. [CrossRef]

34. Pass, R.F.; Duliege, A.M.; Boppana, S.; Sekulovich, R.; Percell, S.; Britt, W.; Burke, R.L. A subunit cytomegalovirus vaccine based on recombinant envelope glycoprotein B and a new adjuvant. J. Infect. Dis. 1999, 180, 970-975. [CrossRef] 
35. Sabbaj, S.; Pass, R.F.; Goepfert, P.A.; Pichon, S. Glycoprotein B vaccine is capable of boosting both antibody and CD4 T-cell responses to cytomegalovirus in chronically infected women. J. Infect. Dis. 2011, 203, 1534-1541. [CrossRef]

36. Bernstein, D.I.; Munoz, F.M.; Callahan, S.T.; Rupp, R.; Wootton, S.H.; Edwards, K.M.; Turley, C.B.; Stanberry, L.R.; Patel, S.M.; Mcneal, M.M.; et al. Safety and efficacy of a cytomegalovirus glycoprotein B (gB) vaccine in adolescent girls: A randomized clinical trial. Vaccine 2016, 34, 313-319. [CrossRef]

37. Griffiths, P.D.; Stanton, A.; McCarrell, E.; Smith, C.; Osman, M.; Harber, M.; Davenport, A.; Jones, G.; Wheeler, D.C.; O'Beirne, J.; et al. Cytomegalovirus glycoprotein-B vaccine with MF59 adjuvant in transplant recipients: A phase 2 randomised placebo-controlled trial. Lancet 2011, 377, 1256-1263. [CrossRef]

38. Spaete, R.R. A recombinant subunit vaccine approach to HCMV vaccine development. Transplant Proc. 1991, 23, 90-96.

39. Sharma, S.; Wisner, T.W.; Johnson, D.C.; Heldwein, E.E. HCMV gB shares structural and functional properties with gB proteins from other herpesviruses. Virology 2013, 435, 239-249. [CrossRef]

40. Cui, X.; Cao, Z.; Wang, S.; Lee, R.B.; Wang, X.; Murata, H.; Adler, S.P.; McVoy, M.A.; Snapper, C.M. Novel trimeric human cytomegalovirus glycoprotein B elicits a high-titer neutralizing antibody response. Vaccine 2018, 36, 5580-5590. [CrossRef]

41. Cui, X.; Snapper, C.M. Combined immunization with human cytomegalovirus envelope proteins elicits strong synergistic neutralizing activity in rabbits. In Proceedings of the Annual Conference on Vaccine Research, NFID, Baltimore, MD, USA, 3-5 April 2019.

42. Vanarsdall, A.L.; Howard, P.W.; Wisner, T.W.; Johnson, D.C. Human Cytomegalovirus gH/gL Forms a Stable Complex with the Fusion Protein gB in Virions. PLoS Pathog. 2016, 12, e1005564. [CrossRef]

43. Cui, X.; Cao, Z.; Chen, Q.; Arjunaraja, S.; Snow, A.L.; Snapper, C.M. Rabbits immunized with Epstein-Barr virus $\mathrm{gH} / \mathrm{gL}$ or $\mathrm{gB}$ recombinant proteins elicit higher serum virus neutralizing activity than gp350. Vaccine 2016, 34, 4050-4055. [CrossRef]

44. Snapper, C.M. Distinct immunologic properties of soluble versus particulate antigens. Front. Immunol. 2018, 9, 598. [CrossRef]

45. Bachmann, M.F.; Jennings, G.T. Vaccine delivery: A matter of size, geometry, kinetics and molecular patterns. Nat. Rev. Immunol. 2010, 10, 787-796. [CrossRef]

46. Rosenberg, A.S. Effects of protein aggregates: An immunologic perspective. AAPS J. 2006, 8, E501-E507. [CrossRef]

47. Cui, X.; Cao, Z.; Sen, G.; Chattopadhyay, G.; Fuller, D.H.; Fuller, J.T.; Snapper, D.M.; Snow, A.L.; Mond, J.J.; Snapper, C.M. A novel tetrameric gp350 1-470 as a potential Epstein-Barr virus vaccine. Vaccine 2013, 31, 3039-3045. [CrossRef]

48. Chuang, T.H.; Lai, C.Y.; Tseng, P.H.; Yuan, C.J.; Hsu, L.C. Development of CpG-oligodeoxynucleotides for effective activation of rabbit TLR9 mediated immune responses. PLoS ONE 2014, 9, e108808. [CrossRef]

49. Kabanova, A.; Marcandalli, J.; Zhou, T.; Bianchi, S.; Baxa, U.; Tsybovsky, Y.; Lilleri, D.; Silacci-Fregni, C.; Foglierini, M.; Fernandez-Rodriguez, B.M.; et al. Platelet-derived growth factor-alpha receptor is the cellular receptor for human cytomegalovirus gHgLgO trimer. Nat. Microbiol. 2016, 1, 16082. [CrossRef]

50. Wu, Y.; Prager, A.; Boos, S.; Resch, M.; Brizic, I.; Mach, M.; Wildner, S.; Scrivano, L.; Adler, B. Human cytomegalovirus glycoprotein complex gH/gL/gO uses PDGFR-alpha as a key for entry. PLoS Pathog. 2017, 13, e1006281. [CrossRef]

51. Stegmann, C.; Hochdorfer, D.; Lieber, D.; Subramanian, N.; Stohr, D.; Laib Sampaio, K.; Sinzger, C. A derivative of platelet-derived growth factor receptor alpha binds to the trimer of human cytomegalovirus and inhibits entry into fibroblasts and endothelial cells. PLoS Pathog. 2017, 13, e1006273. [CrossRef]

52. Wu, K.; Oberstein, A.; Wang, W.; Shenk, T. Role of PDGF receptor-alpha during human cytomegalovirus entry into fibroblasts. Proc. Natl. Acad. Sci. USA 2018, 115, E9889-E9898. [CrossRef]

53. Nguyen, C.C.; Kamil, J.P. Pathogen at the gates: Human cytomegalovirus entry and cell tropism. Viruses 2018, 10, 704. [CrossRef] 
54. Martinez-Martin, N.; Marcandalli, J.; Huang, C.S.; Arthur, C.P.; Perotti, M.; Foglierini, M.; Ho, H.; Dosey, A.M.; Shriver, S.; Payandeh, J. An unbiased screen for human cytomegalovirus identifies neuropilin-2 as a central viral receptor. Cell 2018, 174, 1158-1171. [CrossRef]

55. Chiuppesi, F.; Nguyen, J.; Park, S.; Contreras, H.; Kha, M.; Meng, Z.; Kaltcheva, T.; Iniguez, A.; Martinez, J.; La Rosa, C.; et al. Multiantigenic modified vaccinia virus ankara vaccine vectors to elicit potent humoral and cellular immune reponses against human cytomegalovirus in mice. J. Virol. 2018, 92. [CrossRef]

56. John, S.; Yuzhakov, O.; Woods, A.; Deterling, J.; Hassett, K.; Shaw, C.A.; Ciaramella, G. Multi-antigenic human cytomegalovirus mRNA vaccines that elicit potent humoral and cell-mediated immunity. Vaccine 2018, 36, 1689-1699. [CrossRef]

57. Wang, D.; Freed, D.C.; He, X.; Li, F.; Tang, A.; Cox, K.S.; Dubey, S.A.; Cole, S.; Medi, M.B.; Liu, Y.; et al. A replication-defective human cytomegalovirus vaccine for prevention of congenital infection. Sci. Transl. Med. 2016, 8, 362ra145. [CrossRef]

58. Wen, Y.; Monroe, J.; Linton, C.; Archer, J.; Beard, C.W.; Barnett, S.W.; Palladino, G.; Mason, P.W.; Carfi, A.; Lilja, A.E. Human cytomegalovirus gH/gL/UL128/UL130/UL131A complex elicits potently neutralizing antibodies in mice. Vaccine 2014, 32, 3796-3804. [CrossRef]

59. Freed, D.C.; Tang, Q.; Tang, A.; Li, F.; He, X.; Huang, Z.; Meng, W.; Xia, L.; Finnefrock, A.C.; Durr, E.; et al. Pentameric complex of viral glycoprotein $\mathrm{H}$ is the primary target for potent neutralization by a human cytomegalovirus vaccine. Proc. Natl. Acad. Sci. USA 2013, 110, E4997-E5005. [CrossRef]

60. Macagno, A.; Bernasconi, N.L.; Vanzetta, F.; Dander, E.; Sarasini, A.; Revello, M.G.; Gerna, G.; Sallusto, F.; Lanzavecchia, A. Isolation of human monoclonal antibodies that potently neutralize human cytomegalovirus infection by targeting different epitopes on the gH/gL/UL128-131A complex. J. Virol. 2010, 84, 1005-1013. [CrossRef]

61. Kabanova, A.; Perez, L.; Lilleri, D.; Marcandalli, J.; Agatic, G.; Becattini, S.; Preite, S.; Fuschillo, D.; Percivalle, E.; Sallusto, F.; et al. Antibody-driven design of a human cytomegalovirus gHgLpUL128L subunit vaccine that selectively elicits potent neutralizing antibodies. Proc. Natl. Acad. Sci. USA 2014, 111, 17965-17970. [CrossRef]

62. Wussow, F.; Chiuppesi, F.; Martinez, J.; Campo, J.; Johnson, E.; Flechsig, C.; Newell, M.; Tran, E.; Ortiz, J.; La Rosa, C.; et al. Human cytomegalovirus vaccine based on the envelope gH/gL pentamer complex. PLoS Pathog. 2014, 10, e1004524. [CrossRef]

63. Zydek, M.; Petitt, M.; Fang-Hoover, J.; Adler, B.; Kauvar, L.M.; Pereira, L.; Tabata, T. HCMV infection of human trophoblast progenitor cells of the placenta is neutralized by a human monoclonal antibody to glycoprotein B and not by antibodies to the pentamer complex. Viruses 2014, 6, 1346-1364. [CrossRef]

64. Chiuppesi, F.; Wussow, F.; Johnson, E.; Bian, C.; Zhuo, M.; Rajakumar, A.; Barry, P.A.; Britt, W.J.; Chakraborty, R.; Diamond, D.J. Vaccine-Derived neutralizing antibodies to the human cytomegalovirus gh/gl pentamer potently block primary cytotrophoblast infection. J. Virol. 2015, 89, 11884-11898. [CrossRef]

65. Bootz, A.; Karbach, A.; Spindler, J.; Kropff, B.; Reuter, N.; Sticht, H.; Winkler, T.H.; Britt, W.J.; Mach, M. Protective capacity of neutralizing and non-neutralizing antibodies against glycoprotein B of cytomegalovirus. PLoS Pathog. 2017, 13, e1006601. [CrossRef]

66. Xia, L.; Su, R.; An, Z.; Fu, T.M.; Luo, W. Human cytomegalovirus vaccine development: Immune responses to look into vaccine strategy. Hum. Vaccin. Immunother. 2018, 14, 292-303. [CrossRef]

67. Fouts, A.E.; Comps-Agrar, L.; Stengel, K.F.; Ellerman, D.; Schoeffler, A.J.; Warming, S.; Eaton, D.L.; Feierbach, B. Mechanism for neutralizing activity by the anti-CMV gH/gL monoclonal antibody MSL-109. Proc. Natl. Acad. Sci. USA 2014, 111, 8209-8214. [CrossRef]

68. Loomis, R.J.; Lilja, A.E.; Monroe, J.; Balabanis, K.A.; Brito, L.A.; Palladino, G.; Franti, M.; Mandl, C.W.; Barnett, S.W.; Mason, P.W. Vectored co-delivery of human cytomegalovirus gH and gL proteins elicits potent complement-independent neutralizing antibodies. Vaccine 2013, 31, 919-926. [CrossRef]

69. Baraniak, I.; Kropff, B.; Ambrose, L.; McIntosh, M.; McLean, G.R.; Pichon, S.; Atkinson, C.; Milne, R.S.B.; Mach, M.; Griffiths, P.D.; et al. Protection from cytomegalovirus viremia following glycoprotein B vaccination is not dependent on neutralizing antibodies. Proc. Natl. Acad. Sci. USA 2018, 115, 6273-6278. [CrossRef] 
70. Nelson, C.S.; Huffman, T.; Jenks, J.A.; Cisneros de la Rosa, E.; Xie, G.; Vandergrift, N.; Pass, R.F.; Pollara, J.; Permar, S.R. HCMV glycoprotein B subunit vaccine efficacy mediated by nonneutralizing antibody effector functions. Proc. Natl. Acad. Sci. USA 2018, 115, 6267-6272. [CrossRef]

71. Saccoccio, F.M.; Sauer, A.L.; Cui, X.; Armstrong, A.E.; el Habib, S.E.; Johnson, D.C.; Ryckman, B.J.; Klingelhutz, A.J.; Adler, S.P.; McVoy, M.A. Peptides from cytomegalovirus UL130 and UL131 proteins induce high titer antibodies that block viral entry into mucosal epithelial cells. Vaccine 2011, 29, 2705-2711. [CrossRef]

(C) 2019 by the authors. Licensee MDPI, Basel, Switzerland. This article is an open access article distributed under the terms and conditions of the Creative Commons Attribution (CC BY) license (http://creativecommons.org/licenses/by/4.0/). 